\title{
Mobilization and Distribution of Arsenic with Other Metal Ions at Upstream and Downstream of River Meghna
}

\author{
Kazi Mohammad Anamoul Haquea, Mohd Nur E Alam Siddiqueb iD, A. H. M. Shofiul Islam Molla \\ Jamalc,* (iD, Md Anwarul Islam ${ }^{\text {d }}$
}

${ }^{a}$ Department of Arts \& Science, Bangladesh Army University of Science \& Technology, Saidpur, Bangladesh

${ }^{b}$ Analysis and Development Division, Global Environment Consultant Limited, Dhaka, Bangladesh

c Scientific Officer, Institute of National Analytical Research and Service, BCSIR, Dhaka, Bangladesh

${ }^{d}$ Department of Chemistry, University of Dhaka, Dhaka, Bangladesh

\section{ART I CLE INFO}

Received: 27 June 2019

Revised: 22 September 2019

Accepted: 05 October 2019

Available online: 25 October 2019

\section{K E Y W O R D S}

Arsenic

Other metal

Borehole sediments

Meghna river

Bangladesh

\section{A B S T R A C T}

Geochemical study of toxic metal arsenic along with heavy metals (Fe. Mn and $\mathrm{Cu}$ ), of borehole sediments of the Kushiara and Meghna, rivers in Bangladesh was conducted to investigate the mobilization, distribution and correlation of arsenic with depth, nature of sediment and locations of sampling site, had been included to the study. The Kushiara is the upstream part of Meghna river. Sampling locations were carried out at Sherpur (Moulvibazar) and Beanibazar (Sylhet) for Kushiara river, which is one of the upper stream part of Meghna river. Samplings of borehole sediments collection have been done from Mohonpur (Chandpur) and Chandpur town (Chandpur) for the Meghna river. The borehole sediments were dried in the oven till constant weight and digested it nitric and perchloric acid (3:2) in fume cup hood in the laboratory. The digested sample were analyzed by AgDDTC UV visible Spectrophotmeter for arsenic also analysis of Fe. Mn and $\mathrm{Cu}$ in borehole sediment by Flame AAS. The average concentration of arsenic was found $6.39 \mathrm{mg} / \mathrm{Kg}$ in Borehole sediment for Kushiara river (Beanibazar and Sherpur), $5.00 \mathrm{mg} / \mathrm{Kg}$ for Meghna river (Mohonpur and Chandpur). The highest amount of arsenic $(12.30 \mathrm{mg} / \mathrm{Kg})$ was found in grayish clay type sediment at upstream of Kushiara river at Beanibazar. It is evident from the study, that arsenic is mobilized from upper stream to lower stream. In addition, it also reveals that high amount of $\mathrm{Fe}$ and $\mathrm{Mn}$ was in sediment sample. Statistical analysis shows that arsenic is strongly correlated with $\mathrm{Mn}$ and Fe but weakly correlated with $\mathrm{Cu}$. In nature $\mathrm{FeOOH}$ occurs is yellowish in color and $\mathrm{MnOOH}$ is gray in color, these two of oxy-hydroxides may be scavengers of arsenic. It was indicated that the occurrence of $\mathrm{FeSO}_{4}, \mathrm{MnSO}_{4}$ and $\mathrm{CuSO}_{4}$ is predominant in all of the borehole sediment of Kushiara and Meghna rivers. 


\section{GRAPHICALABSTRACT}

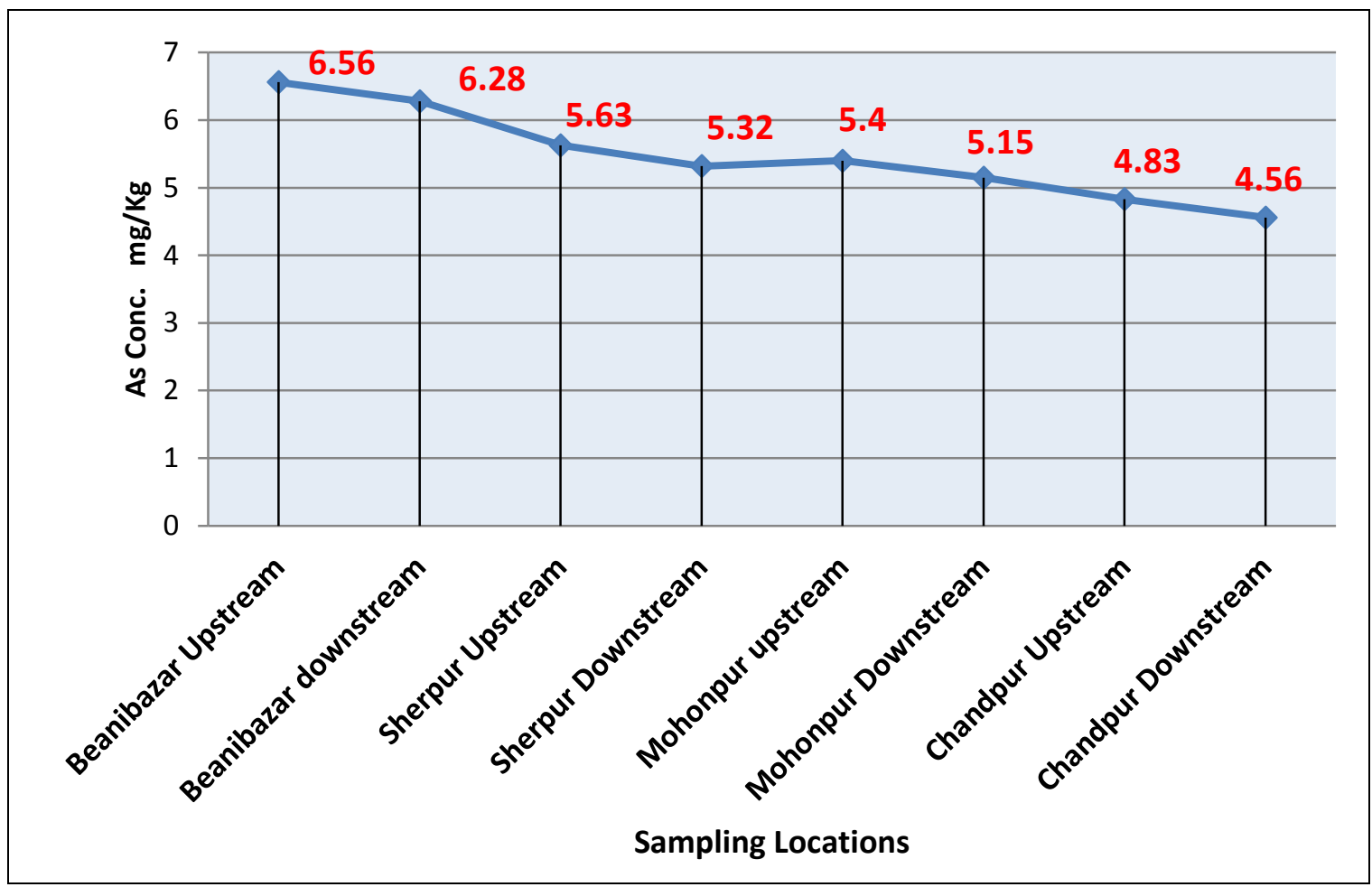

\section{Introduction}

Arsenic occurs in large quantities in the earth's crust and in trace quantities in rocks, soil, water [1] and some in ambient air [2]. Vertical distribution of both solid and dissolved As $\left(\mathrm{As}^{3+}\right.$ and $\left.\mathrm{As}^{5+}\right)$ in recent sediment shows a novel pattern of the element [3]. Moreover, particulate arsenic entering estuaries [4] remained in the solid phase and accumulated in sedimentary deposits. The clinical manifestations of chronic arsenicosis in humans include the noncancerous skin disorders hyper- and hypo pigmentation, keratosis, cardiovascular disease and neurological complications [5-7]. Arsenic toxicity strongly depends on the form in which arsenic is present. Inorganic arsenic forms, typical in drinking water, are much more toxic than organic ones that are present in sea food. Inorganic arsenic compounds in which arsenic is present in trivalent form are known to be the most toxic. Toxicity is expressed as the number of milligrams of the compound per kilogram of body weight that will result within a few days in the death of half of those who ingest it in a single dose. The acute minimal lethal dose of arsenic in adults is estimated to be 70 to $200 \mathrm{mg}$ or $1 \mathrm{mg} / \mathrm{kg} /$ day. Most reported arsenic poisonings are caused by one of arsenic's compounds, also found in drinking water, arsenic trioxide which is 500 times more toxic than pure arsenic [8-10]. UNICEF and other international agencies helped to install more than four million hand-pumped wells in Bangladesh to give communities access to clean drinking water and to reduce diarrhoea and infant mortality [11]. Cases of arsenicosis were seen in West Bengal and then in Bangladesh in the 1980s. Though in 1983, the first arsenic patients seen were from West Bengal, India but it come to consideration and confirmed in 1993 in the Chapai Nawabganj (CN), Bangladesh (DPHE, 1993). But at present the contamination has affected 59 of the 64 districts in Bangladesh where arsenic levels have been found to be 
above the nationally (50 ppb) accepted limit. It is estimated that about 125 million inhabitants of Bangladesh between 35 million and 77 million are at risk of drinking contaminated [12] water (IAEA, 2002)].

Arsenic occurs as a major constituent in more than 200 minerals [13], including elemental arsenic, arsenides, sulphides, oxides, arsenates and arsenates. The most abundant as ore mineral is arsenopyrite, FeAsS. It is generally accepted that arsenopyrite, together with the other dominant As-sulphide minerals realgar and orpiment, are only formed under high temperature conditions in the earth's crust. Values of arsenic are typically $3-10 \mathrm{mg} / \mathrm{kg}^{-1}$, depending on texture and mineralogy of sediments. Elevated concentrations tend to reflect the amounts of pyrite or Fe oxides present. Increases are also typically found in mineralized areas. Placer deposits in streams can have very high concentrations as a result of the abundance of sulphide minerals [14].

The Bengal Delta Plain (BDP) is one of the biggest deltas in the world and through which the rivers Padma (Ganges), Jamuna (Brahmaputra) and Megnha pass into the Bay of Bengal. The rivers generate large amounts of sediments each year and therefore alluvial sediments dominate the geology. The main part of the BDP is located in Bangladesh. The Bengal basin has one border to the north to the Shillong plateau (an extension to the Himalayas) and another to the east through the Tripura Hills. The third border is constituted by the Indian shield (a Precambrian basement complex). Kushiara alluvial fan of the northeast Bengal basin which is coming from the Barak river of India and originating from the Manipur Hills. The Kushiara is also known as the Kalni river after it is joined by a major offshoot from the Surma river. When the Surma and the Kushiara finally rejoin in Kishoreganj District above Bhairab Bazar, the river is known as the Meghna river. The river meets Padma river in Chandpur District. Finally it then flows into the Bay of Bengal as name of the Meghna river. The aim of the study to measure arsenic in the borehole sediment from 1-6 m depth at the river Kushiara and Meghna river along with $\mathrm{Fe}, \mathrm{Cu}, \mathrm{Mg}$, and finding a correlation of arsenic with metal ions.

\section{Experimental}

\section{Sampling locations}

Four locations were selected as 8 ( Eight) sampling sites at entering point (upstream) and end point (downstream) of two rivers; Kushiara and Meghna in Bangladesh at 2013 (June). Among four locations first location was Beanibazar of Sylhet district. Beanibazar is the entering point of Kushiara river. Second location was Sherpur in Moulvibazar district. Sherpur is the lower stream of Kushiara river. Third location was Mohonpur in Chandpur district. Mohonpur is the upper stream of Meghna river. Fourth location was Chandpur town in Chadpur district. Chadpur is the confluence of Meghna river and Padma river.

\section{Digestion procedure of sediments}

The sediment samples were digested following the $\mathrm{HNO}_{3}$ and $\mathrm{HClO}_{4}$ Digestion method [16]. Both the acids were analytical reagent grade. Accurately weighed amount $(0.1 \mathrm{~g})$ of the sample was taken in a Teflon acid bomb. $3.0 \mathrm{~mL}$ of nitric acid and $2.0 \mathrm{~mL}$ of perchloric acid were added to the sample. Then the acid bomb was placed in an oven for heating at $200{ }^{\circ} \mathrm{C}$ for two hours. After digestion, the sample was cooled, filtered and transferred to a $25.0 \mathrm{~mL}$ volumetric flask. The solution was then made up to the mark with the help of distilled de-ionized water. The sample solutions were then transferred in plastic bottles and preserved in freeze at $4{ }^{\circ} \mathrm{C}$. 
Figure 1. Sampling location for borehole sediments

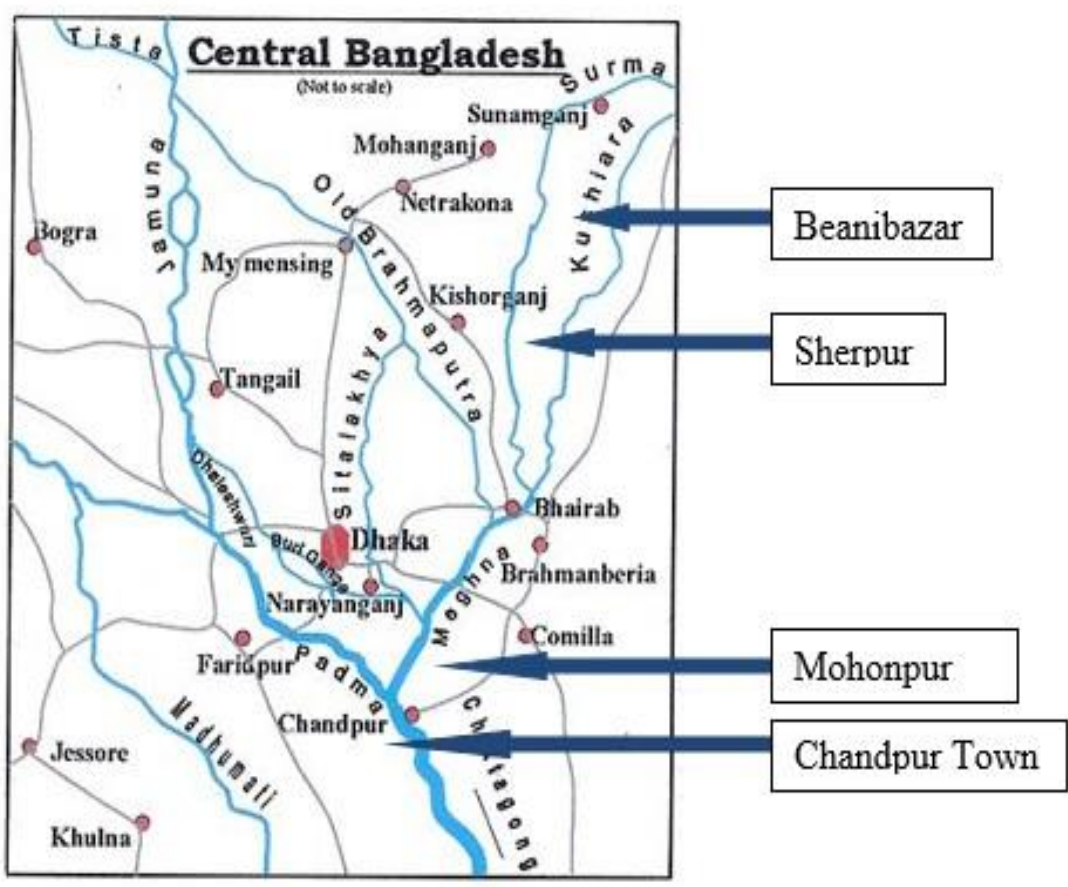

\begin{tabular}{|c|c|c|c|}
\hline Location & Latitude & Longitude & Altitude \\
\hline Beanibazar Upstream & 24043'06.87" & $92^{\circ 0} 00^{\prime} 19.99^{\prime \prime}$ & $48 \mathrm{ft}$ \\
\hline Beanibazar Downstream & $24042^{\prime} 43.40 \prime$ & 91059'01.69" & $52 \mathrm{ft}$ \\
\hline Sherpur Upstrem & $24038^{\prime} 22.14^{\prime \prime}$ & 91039'23.79" & $40 \mathrm{ft}$ \\
\hline Sherpur Downstrem & 24037'19.63" & $91^{040} 58.81^{\prime \prime}$ & $46 \mathrm{ft}$ \\
\hline Mohonpur Upstrem & $23^{047} 56.07 "$ & $89048^{\prime} 45.34 \prime$ & $40 \mathrm{ft}$ \\
\hline Mohonpur Downstrem & $23^{0} 22^{\prime} 57.59^{\prime \prime}$ & $90^{0} 25^{\prime} 38.88^{\prime \prime}$ & $29 \mathrm{ft}$ \\
\hline Chandpur Upstrem & $23^{0} 22^{\prime} 54.29^{\prime \prime}$ & $90^{0} 36^{\prime} 25.65^{\prime \prime}$ & $30 \mathrm{ft}$ \\
\hline Chandpur Downstrem & $23^{0} 11^{\prime} 06.64^{\prime \prime}$ & $90^{0} 38^{\prime} 55.06^{\prime \prime}$ & $20 \mathrm{ft}$ \\
\hline
\end{tabular}

\section{Method of analysis for arsenic}

Inorganic arsenic is reduced to arsine by zinc in acid solution in a Gutzeit generation (modified). The arsine is then passed through a scrubber containing glass wool impregnated with lead acetate solution and into an absorber tube containing Ag-DDTC dissolved in chloroform or pyridine. In the absorber arsenic reacts with the silver salt, forming a soluble red complex suitable for photometric measurement at $540 \mathrm{~nm}$.

\section{Method of analysis}

The metal ions ( $\mathrm{Fe}, \mathrm{Mn}$ and $\mathrm{Cu}$ ) has been determinate by AAS with air acetylene flame.
Digested sample solutions wer directly aspiration to the AAS flame with default condition of each above metal ions.

\section{Results and Discussion}

Concentrations of As and other heavy metals from borehole sediment (sixty four) samples, upper soil (eight) and edge soil (eight) sample at up and down stream of both river the Kushiara and the Meghna. The concentration of $\mathrm{Fe}$ is in $\mathrm{g}$ $\mathrm{Kg}^{-1}$ and that of other three metals As, Mn and $\mathrm{Cu}$ are expressed in $\mathrm{mg} \mathrm{Kg}^{-1}$. The concentration of arsenic was varied from upper and downstream at different depths of every sampling location due to geochemical, 
biogeochemical transformation and geophysical aspect of sediments, rocks and different ores present in soil. The results of arsenic, copper, iron and $\mathrm{Mn}$ are in the table from 1.1 to 1.8.

Greater fraction of arsenic was found in clay and gray colored sediment. Yellowish colour of sediment indicates the presence of iron-oxy-

Figure 2. Arsine Gas Generation in Laboratory hydroxide (FeOOH -Goethite) and grayish color might be for manganese-oxy-hydroxide (MnOOH Groutite). Both iron and manganese amount were found in high by atomic absorption spectroscopic quantitative analysis. Arsenic is found in yellow and grayish sediment in high percentages.

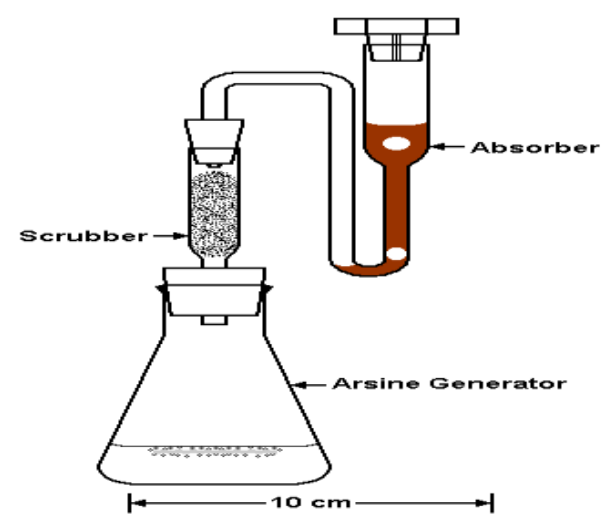

Table 1.1. Physical properties of sediments and concentrations of $\mathrm{As}, \mathrm{Fe}, \mathrm{Mn}$ and $\mathrm{Cu}$ in sediments of Kushiara river in Beanibazar (upstream)

\begin{tabular}{|c|c|c|c|c|c|c|}
\hline $\begin{array}{l}\text { Sampling } \\
\text { site }\end{array}$ & & Depth & $\begin{array}{c}\text { As } \\
\text { (mg/Kg) }\end{array}$ & $\begin{array}{c}\mathrm{Fe} \\
(\mathrm{g} / \mathrm{Kg})\end{array}$ & $\begin{array}{c}\mathrm{Mn} \\
(\mathrm{mg} / \mathrm{Kg})\end{array}$ & $\begin{array}{c}\mathrm{Cu} \\
(\mathrm{mg} / \mathrm{Kg})\end{array}$ \\
\hline Sample & Upper soil & & 4.35 & 20.43 & 336.15 & 821.14 \\
\hline ID & Edge soil & & 4.50 & 18.45 & 645.72 & 784.67 \\
\hline KBU-1 & & $1 \mathrm{~m}$ & 5.25 & 24.46 & 283.14 & 847.44 \\
\hline KBU-2 & & $2 \mathrm{~m}$ & 5.37 & 31.05 & 375.73 & 845.53 \\
\hline KBU-3 & & $3 \mathrm{~m}$ & 6.20 & 47.25 & 296.57 & 314.54 \\
\hline KBU-4 & & $4 \mathrm{~m}$ & 6.80 & 36.23 & 273.29 & 410.55 \\
\hline KBU-5 & & $5 \mathrm{~m}$ & 7.70 & 34.35 & 254.16 & 563.36 \\
\hline KBU-6 & & $6 \mathrm{~m}$ & 12.30 & 46.35 & 208.81 & 646.89 \\
\hline
\end{tabular}

Table 1.2. Physical properties of sediments and concentrations of $\mathrm{As}, \mathrm{Fe}, \mathrm{Mn}$ and $\mathrm{Cu}$ in sediments of Kushiara river in Beanibazar (downstream)

\begin{tabular}{|c|c|c|c|c|c|c|}
\hline \multicolumn{2}{|c|}{$\begin{array}{l}\text { Sampling } \\
\text { site }\end{array}$} & Depth & $\begin{array}{c}\text { As } \\
(\mathrm{mg} / \mathrm{Kg})\end{array}$ & $\begin{array}{c}\mathrm{Fe} \\
(\mathrm{g} / \mathrm{Kg})\end{array}$ & $\begin{array}{c}\mathrm{Mn} \\
(\mathrm{mg} / \mathrm{Kg})\end{array}$ & $\begin{array}{c}\mathrm{Cu} \\
(\mathrm{mg} / \mathrm{Kg})\end{array}$ \\
\hline Sample & Upper soil & & 5.09 & 15.15 & 445.17 & 325.35 \\
\hline ID & Edge soil & & 5.30 & 19.70 & 388.81 & 426.18 \\
\hline KBD-1 & & $1 \mathrm{~m}$ & 5.26 & 19.51 & 481.34 & 719.79 \\
\hline KBD-2 & & $2 \mathrm{~m}$ & 5.64 & 23.16 & 513.80 & 813.55 \\
\hline KBD-3 & & $3 \mathrm{~m}$ & 6.12 & 21.45 & 384.48 & 619.24 \\
\hline KBD-4 & & $4 \mathrm{~m}$ & 7.79 & 33.65 & 323.97 & 1290.43 \\
\hline KBD-5 & & $5 \mathrm{~m}$ & 8.79 & 29.10 & 258.66 & 915.76 \\
\hline KBD-6 & & $6 \mathrm{~m}$ & 6.24 & 25.37 & 201.73 & 1371.26 \\
\hline
\end{tabular}


Table 1.3. Physical properties of sediments and concentrations of As, Fe, $\mathrm{Mn}$ and $\mathrm{Cu}$ in sediments of Kushiara River in Sherpur (upstream)

\begin{tabular}{ccccccc}
\multicolumn{2}{c}{$\begin{array}{c}\text { Sampling } \\
\text { site }\end{array}$} & Depth & $\begin{array}{c}\mathrm{As} \\
(\mathrm{mg} / \mathrm{Kg})\end{array}$ & $\begin{array}{c}\mathrm{Fe} \\
(\mathrm{g} / \mathrm{Kg})\end{array}$ & $\begin{array}{c}\mathrm{Mn} \\
(\mathrm{mg} / \mathrm{Kg})\end{array}$ & $\begin{array}{c}\mathrm{Cu} \\
(\mathrm{mg} / \mathrm{Kg})\end{array}$ \\
$\begin{array}{c}\text { Sample } \\
\text { ID }\end{array}$ & Upper soil & & 3.40 & 11.20 & 735.00 & 513.00 \\
& Edge soil & & & & & \\
KSU-1 & & 5.21 & 15.12 & 660.00 & 1257.50 \\
KSU-2 & $2 \mathrm{~m}$ & 5.23 & 13.78 & 159.50 & 1042.00 \\
KSU-3 & $3 \mathrm{~m}$ & 5.24 & 24.10 & 168.49 & 759.65 \\
KSU-4 & $4 \mathrm{~m}$ & 5.69 & 17.75 & 171.69 & 493.50 \\
KSU-5 & $5 \mathrm{~m}$ & 7.27 & 11.30 & 153.34 & 774.12 \\
KSU-6 & $6 \mathrm{~m}$ & 6.76 & 19.13 & 187.37 & 507.61 \\
& & & & & & \\
\hline
\end{tabular}

Table 1.4. Physical properties of sediments and concentrations of $\mathrm{As}, \mathrm{Fe}, \mathrm{Mn}$ and $\mathrm{Cu}$ in sediments of Kushiara river in Sherpur (downstream)

\begin{tabular}{ccccccc}
\multicolumn{2}{c}{$\begin{array}{c}\text { Sampling } \\
\text { site }\end{array}$} & Depth & $\begin{array}{c}\mathrm{As} \\
(\mathrm{mg} / \mathrm{Kg})\end{array}$ & $\begin{array}{c}\mathrm{Fe} \\
(\mathrm{g} / \mathrm{Kg})\end{array}$ & $\begin{array}{c}\mathrm{Mn} \\
(\mathrm{mg} / \mathrm{Kg})\end{array}$ & $\begin{array}{c}\mathrm{Cu} \\
(\mathrm{mg} / \mathrm{Kg})\end{array}$ \\
$\begin{array}{c}\text { Sample } \\
\text { ID }\end{array}$ & Upper soil & & 3.80 & 38.95 & 779.50 & 1327.50 \\
& Edge soil & & 4.16 & 33.79 & 642.50 & 1295.00 \\
KSD-1 & & $1 \mathrm{~m}$ & 4.70 & 36.00 & 395.00 & 1650.26 \\
KSD-2 & $2 \mathrm{~m}$ & 4.79 & 31.18 & 411.65 & 1148.61 \\
KSD-3 & $3 \mathrm{~m}$ & 5.10 & 23.20 & 425.71 & 1184.14 \\
KSD-4 & $4 \mathrm{~m}$ & 8.10 & 19.75 & 517.94 & 974.36 \\
KSD-5 & $5 \mathrm{~m}$ & 6.70 & 27.15 & 601.29 & 804.52 \\
KSD-6 & $6 \mathrm{~m}$ & 5.17 & 25.16 & 429.49 & 724.51 \\
\hline
\end{tabular}

Table 1.5. Physical properties of sediments and concentrations of $\mathrm{As}, \mathrm{Fe}, \mathrm{Mn}$ and $\mathrm{Cu}$ in sediments of Meghna river in Mohonpur (upstream)

\begin{tabular}{|c|c|c|c|c|c|c|}
\hline \multicolumn{2}{|c|}{$\begin{array}{l}\text { Sampling } \\
\text { site }\end{array}$} & \multirow[t]{2}{*}{ Depth } & \multirow{2}{*}{$\begin{array}{c}\text { As } \\
\text { (mg/Kg) } \\
2.63\end{array}$} & \multirow{2}{*}{$\begin{array}{c}\mathrm{Fe} \\
(\mathrm{g} / \mathrm{Kg}) \\
19.48\end{array}$} & \multirow{2}{*}{$\begin{array}{c}\mathrm{Mn} \\
(\mathrm{mg} / \mathrm{Kg}) \\
233.08\end{array}$} & \multirow{2}{*}{$\begin{array}{c}\mathrm{Cu} \\
(\mathrm{mg} / \mathrm{Kg}) \\
155.87\end{array}$} \\
\hline $\begin{array}{c}\text { Sample } \\
\text { ID }\end{array}$ & Upper soil & & & & & \\
\hline & Edge soil & & 3.55 & 11.91 & 331.47 & 315.25 \\
\hline MMU-1 & & $1 \mathrm{~m}$ & 4.21 & 12.05 & 272.50 & 246.85 \\
\hline MMU-2 & & $2 \mathrm{~m}$ & 4.38 & 14.55 & 295.17 & 568.41 \\
\hline MMU-3 & & $3 \mathrm{~m}$ & 6.21 & 18.55 & 198.26 & 412.14 \\
\hline MMU-4 & & $4 \mathrm{~m}$ & 6.35 & 19.58 & 214.31 & 725.18 \\
\hline MMU-5 & & $5 \mathrm{~m}$ & 7.50 & 44.05 & 345.21 & 315.12 \\
\hline MMU-6 & & $6 \mathrm{~m}$ & 8.31 & 23.14 & 245.07 & 290.47 \\
\hline
\end{tabular}


Table1.6. Physical properties of sediments and concentrations of $\mathrm{As}, \mathrm{Fe}, \mathrm{Mn}$ and $\mathrm{Cu}$ in sediments of Meghna river in Mohonpur (downstream)

\begin{tabular}{|c|c|c|c|c|c|c|}
\hline \multicolumn{2}{|c|}{$\begin{array}{l}\text { Sampling } \\
\text { site }\end{array}$} & \multirow[t]{2}{*}{ Depth } & \multirow{2}{*}{$\begin{array}{c}\text { As } \\
(\mathrm{mg} / \mathrm{Kg}) \\
2.64\end{array}$} & \multirow{2}{*}{$\begin{array}{c}\mathrm{Fe} \\
(\mathrm{g} / \mathrm{Kg}) \\
11.85\end{array}$} & \multirow{2}{*}{$\begin{array}{c}\mathrm{Mn} \\
(\mathrm{mg} / \mathrm{Kg}) \\
672.28\end{array}$} & \multirow{2}{*}{$\begin{array}{c}\mathrm{Cu} \\
(\mathrm{mg} / \mathrm{Kg}) \\
240.51\end{array}$} \\
\hline Sample & Upper soil & & & & & \\
\hline & Edge soil & & 3.39 & 19.48 & 155.50 & 196.00 \\
\hline MMD-1 & & $1 \mathrm{~m}$ & 4.13 & 19.85 & 607.50 & 302.72 \\
\hline MMD-2 & & $2 \mathrm{~m}$ & 4.29 & 21.54 & 313.16 & 321.39 \\
\hline MMD-3 & & $3 \mathrm{~m}$ & 7.89 & 25.16 & 379.41 & 303.72 \\
\hline MMD-4 & & $4 \mathrm{~m}$ & 5.45 & 41.30 & 354.31 & 336.13 \\
\hline MMD-5 & & $5 \mathrm{~m}$ & 5.97 & 13.95 & 235.15 & 356.17 \\
\hline MMD-6 & & $6 \mathrm{~m}$ & 7.45 & 42.10 & 202.75 & 405.78 \\
\hline
\end{tabular}

Table 1.7. Physical properties of sediments and concentrations of $\mathrm{As}, \mathrm{Fe}, \mathrm{Mn}$ and $\mathrm{Cu}$ in sediments of Meghna river in Chandpur (upstream)

\begin{tabular}{ccccccc}
\multicolumn{2}{c}{$\begin{array}{c}\text { Sampling } \\
\text { site }\end{array}$} & Depth & $\begin{array}{c}\mathrm{As} \\
(\mathrm{mg} / \mathrm{Kg})\end{array}$ & $\begin{array}{c}\mathrm{Fe} \\
(\mathrm{g} / \mathrm{Kg})\end{array}$ & $\begin{array}{c}\mathrm{Mn} \\
(\mathrm{mg} / \mathrm{Kg})\end{array}$ & $\begin{array}{c}\mathrm{Cu} \\
(\mathrm{mg} / \mathrm{Kg})\end{array}$ \\
$\begin{array}{c}\text { Sample } \\
\text { ID }\end{array}$ & Upper soil & & 1.90 & 20.05 & 380.67 & 645.12 \\
& Edge soil & & 3.49 & 15.35 & 209.35 & 429.27 \\
MCU-1 & & $1 \mathrm{~m}$ & 3.83 & 28.49 & 492.16 & 370.15 \\
MCU-2 & $2 \mathrm{~m}$ & 3.89 & 37.45 & 416.31 & 311.58 \\
MCU-3 & $3 \mathrm{~m}$ & 5.64 & 23.45 & 355.50 & 206.18 \\
MCU-4 & $4 \mathrm{~m}$ & 5.80 & 23.48 & 514.45 & 211.35 \\
MCU-5 & $5 \mathrm{~m}$ & 7.19 & 34.75 & 310.15 & 158.39 \\
MCU-6 & $6 \mathrm{~m}$ & 6.96 & 19.12 & 455.12 & 144.35 \\
\hline
\end{tabular}

Table 1.8. Physical properties of sediments and concentrations of $\mathrm{As}, \mathrm{Fe}, \mathrm{Mn}$ and $\mathrm{Cu}$ in sediments of Meghna river in Chandpur (downstream)

\begin{tabular}{ccccccc}
\multicolumn{2}{c}{$\begin{array}{c}\text { Sampling } \\
\text { site }\end{array}$} & Depth & $\begin{array}{c}\mathrm{As} \\
(\mathrm{mg} / \mathrm{Kg})\end{array}$ & $\begin{array}{c}\mathrm{Fe} \\
(\mathrm{g} / \mathrm{Kg})\end{array}$ & $\begin{array}{c}\mathrm{Mn} \\
(\mathrm{mg} / \mathrm{Kg})\end{array}$ & $\begin{array}{c}\mathrm{Cu} \\
(\mathrm{mg} / \mathrm{Kg})\end{array}$ \\
$\begin{array}{c}\text { Sample } \\
\text { ID }\end{array}$ & Upper soil & & 1.71 & 15.55 & 531.81 & 403.18 \\
& Edge soil & & & & & \\
MCD-1 & & $1 \mathrm{~m}$ & 3.59 & 23.45 & 461.72 & 752.00 \\
MCD-2 & $2 \mathrm{~m}$ & 5.18 & 12.12 & 549.63 & 456.16 \\
MCD-3 & $3 \mathrm{~m}$ & 4.63 & 32.89 & 561.25 & 594.21 \\
MCD-4 & $4 \mathrm{~m}$ & 5.48 & 41.89 & 550.35 & 584.91 \\
MCD-5 & $5 \mathrm{~m}$ & 6.39 & 24.15 & 365.81 & 453.42 \\
MCD-6 & $6 \mathrm{~m}$ & 6.88 & 28.17 & 275.20 & 305.48 \\
\hline
\end{tabular}

Therefore both iron-oxy-hydroxide and manganese-oxyhydroxide are two main sources for being scavenge of arsenic in sediment.

The average amount of arsenic involving upper and edge soil with borehole sediment is less than that only inclined with borehole sediment. It indicates that arsenic may be liberated in surface and near surface sediment through cyclic redox condition and subsequently transported to well depth. This is very possible 
as the types of sediments vary from on average types of Silty, sandy or clay to coarse or sandy along vertical soil column.

The lesser adsorption or accumulation of arsenic on to the sand, coarse sediments due to the small surface area facilitates the movement of arsenic along the down ward sandy passage of soil column since the fine grained silt or sand

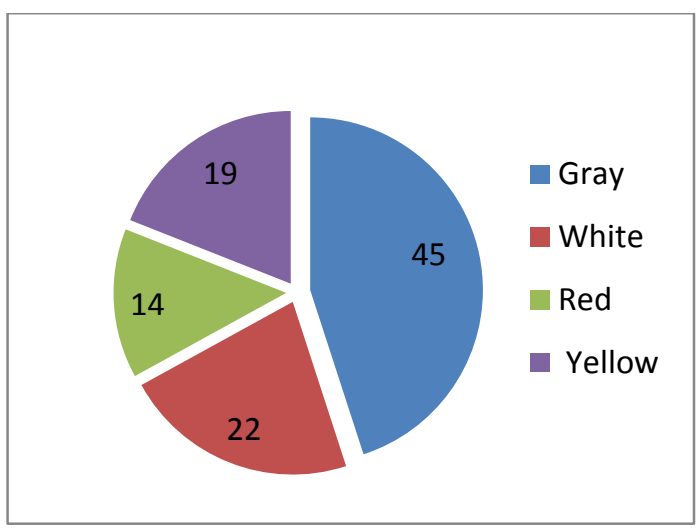

(a) or finest clay can leach easily through the pores of sand barrier. These types of particles having greater surface area can absorb greater fraction of arsenic on their surfaces and hence can easily act as depository or scavenger of arsenic and carry arsenic into lower ground level. Again highest average concentration of arsenic was in grayish colored sediment samples.

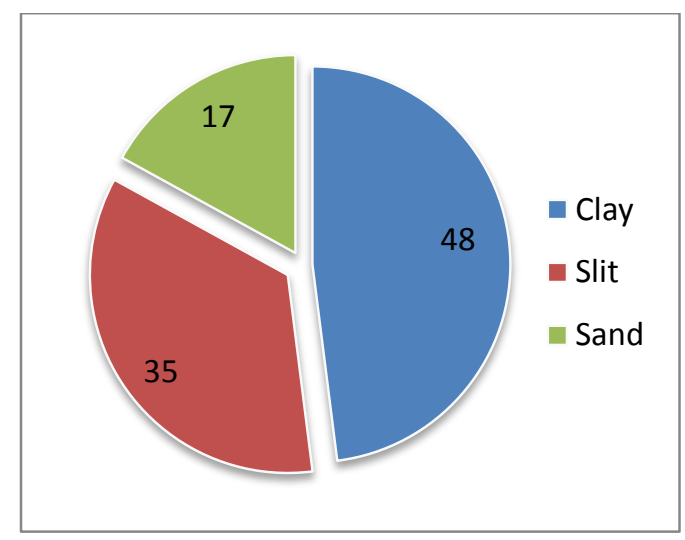

(b)

Figure 3. Distribution of As in different a) colored b) types of sediments

Figure 4. Average

concentration of As in different colored sediments in $(\mathrm{mg} / \mathrm{kg})$

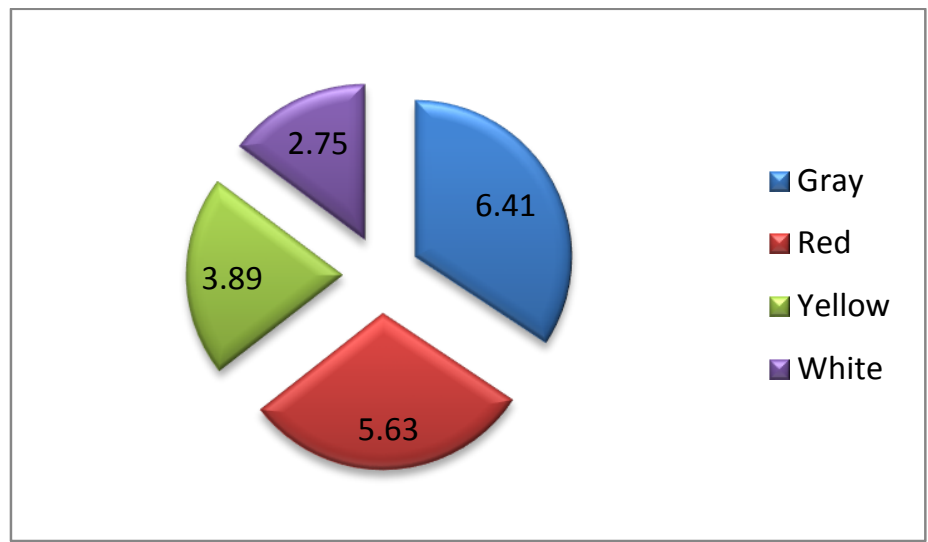

Kushiara upstream at Beanibazar

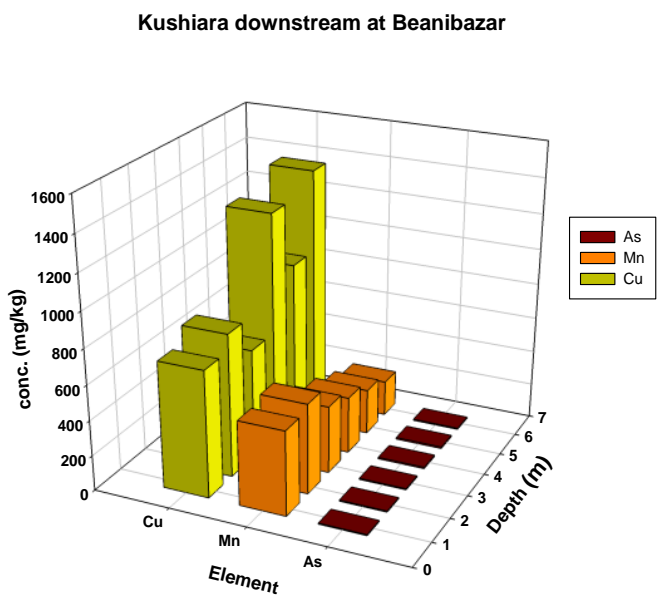


Kushiara upstream at Sherpur

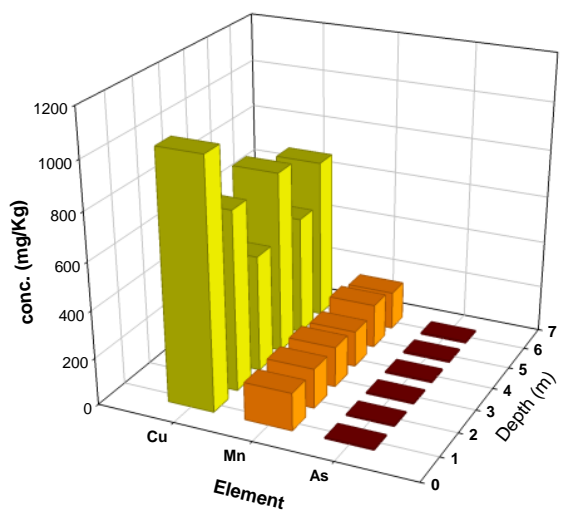

Meghna upstream at Mohonpur

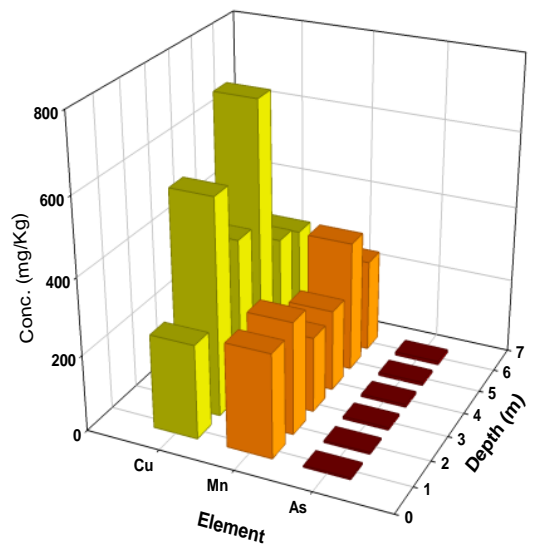

Meghna upstream at Chandpur

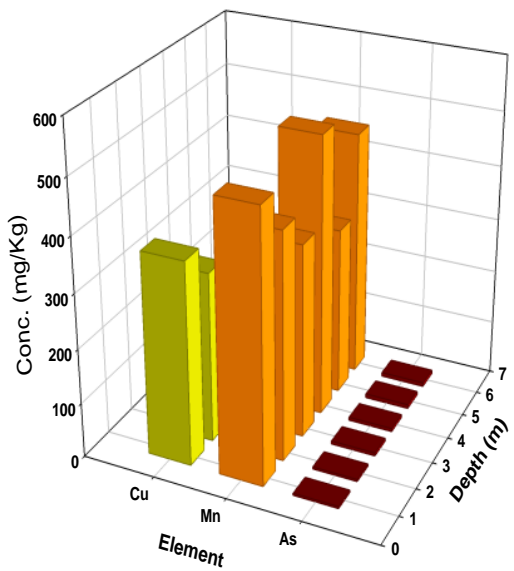

Kushiara downstream at Sherpur

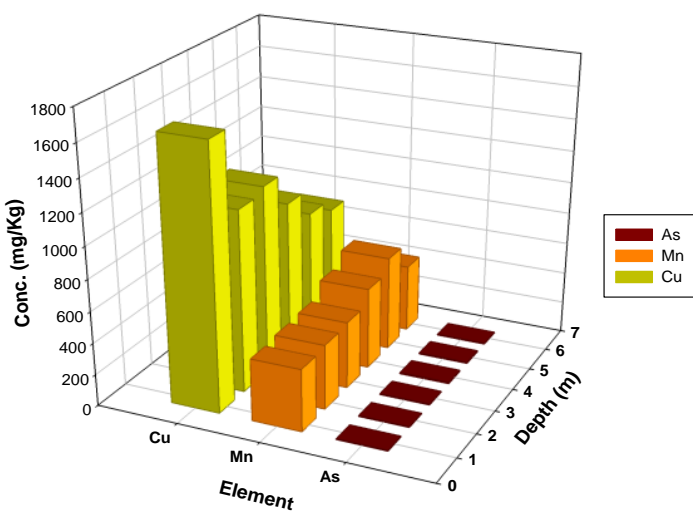

Meghna downstream at Mohonpur

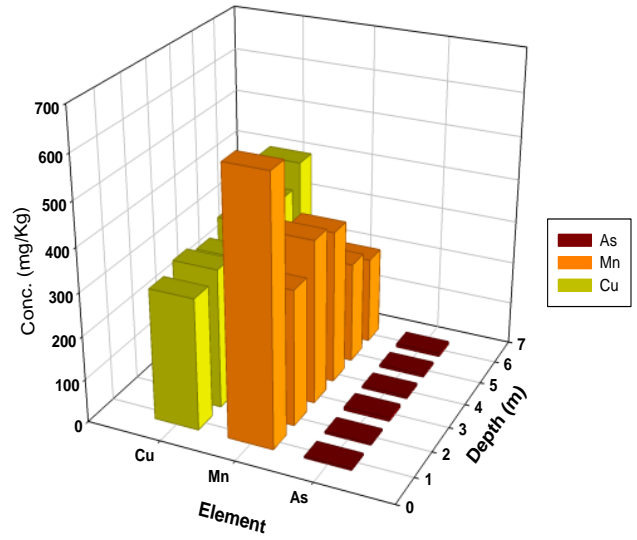

Meghna downstream at Chandpur

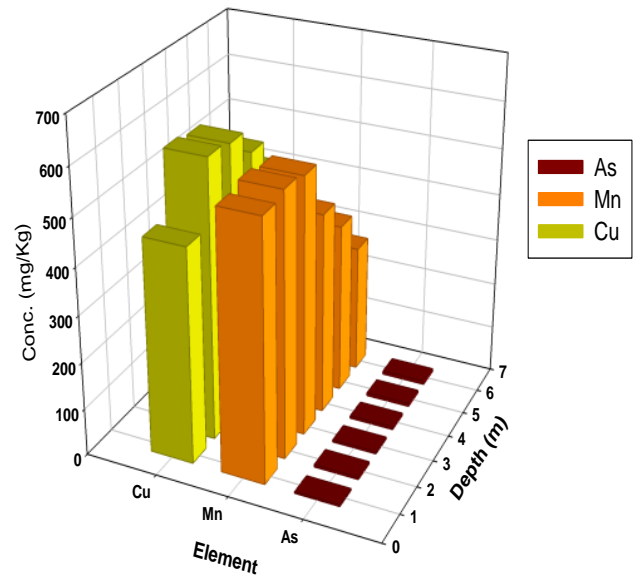

Figure 5. Distribution of $\mathrm{As}, \mathrm{Mn}$ and $\mathrm{Cu}$ in the sediments of 1-6 $\mathrm{m}$ depth at the different sampling locations

Average arsenic concentrations of borehole sediments from 1-6 m depth were $6.56 \mathrm{mg} / \mathrm{Kg}^{-1}$, $6.28 \mathrm{mg} / \mathrm{Kg}^{-1}$ in up and downstream respectively at Beanibazar (Sylhet) of the
Kushiara River. The concentrations of arsenic were $5.63 \mathrm{mg} / \mathrm{Kg}^{-1}$ and $5.32 \mathrm{mg} / \mathrm{Kg}^{-1}$ in up and downstream respectively at Sherpur (Moulvibazar) of Kushiara River. The 
concentrations of arsenic were $5.40 \mathrm{mg} / \mathrm{Kg}^{-1}$ and $5.15 \mathrm{mg} / \mathrm{Kg}^{-1}$ found at upstream and downstream respectively at Mohonpur (Chandpur) of Meghna river. Arsenic concentrations were found $4.83 \mathrm{mg} / \mathrm{Kg}^{-1}$ and $4.56 \mathrm{mg} / \mathrm{Kg}^{-1}$ in up and downstream respectively at Chandpur town (Chandpur) of Meghna river.

Average $\mathrm{Fe}$ concentrations in borehole sediments from 1-6 m depth were $32.32 \mathrm{~g} / \mathrm{Kg}^{-1}$, $23.39 \mathrm{~g} \mathrm{Kg}^{-1}$ in up and downstream respectively at Beanibazar (Sylhet) for Kushiara River. The concentrations of Fe were $16.78 \mathrm{~g} / \mathrm{Kg}^{-1}$ and $39.40 \mathrm{~g} \mathrm{Kg}^{-1}$ in up and downstream respectively at Sherpur (Moulvibazar) of Kushiara River. The concentrations of Fe were $20.41 \mathrm{~g} / \mathrm{Kg}^{-1}$ and $24.40 \mathrm{~g} / \mathrm{Kg}^{-1}$ found in up and downstream respectively at Mohonpur (Chandpur) for Meghna River. Fe was found $25.27 \mathrm{~g} / \mathrm{Kg}^{-1}$ and $24.93 \mathrm{~g} \mathrm{Kg}^{-1}$ in up and downstream respectively at Chandpur town (Chandpur) of Meghna river.

Average $\mathrm{Mn}$ concentration in borehole sediments from 1-6 m depth was $334.20 \mathrm{mg}$ $\mathrm{Kg}^{-1}, 374.75 \mathrm{mg} / \mathrm{Kg}^{-1}$ in up and downstream respectively at Beanibazar (Sylhet) of Kushiara river. The concentrations of Mn were $299.74 \mathrm{mg}$ $\mathrm{Kg}^{-1}$ and $525.39 \mathrm{mg} / \mathrm{Kg}^{-1}$ in up and downstream respectively at Sherpur (Moulvibazar) for Kushiara river. The concentrations of Mn were $268.88 \mathrm{mg} / \mathrm{Kg}^{-1}$ and $365.01 \mathrm{mg} / \mathrm{Kg}^{-1}$ found in up and downstream respectively at Mohonpur (Chandpur) for Meghna River. Mn was found $391.78 \mathrm{mg} / \mathrm{Kg}^{-1}$ and $465.99 \mathrm{mg} / \mathrm{Kg}^{-1}$ in up and down stream respectively at Chandpur town (Chandpur) of Meghna river.

Average $\mathrm{Cu}$ concentrations in borehole sediments from 1-6 $\mathrm{m}$ depth were $654.27 \mathrm{mg}$ $\mathrm{Kg}^{-1}, 410.20 \mathrm{mg} / \mathrm{Kg}^{-1}$ in up and downstream respectively at Beanibazar (Sylhet) for Kushiara river. The concentrations of $\mathrm{Cu}$ were $454.24 \mathrm{mg}$ $\mathrm{Kg}^{-1}$ and $1138.62 \mathrm{mg} / \mathrm{Kg}^{-1}$ in up and downstream respectively at Sherpur (Moulvibazar) for Kushiara river. The concentrations of $\mathrm{Cu}$ were $378.67 \mathrm{mg} / \mathrm{Kg}^{-1}$ and $307.80 \mathrm{mg} / \mathrm{Kg}^{-1}$ found in up and downstream respectively at Mohonpur (Chandpur) of Meghna river. $\mathrm{Cu}$ were found $319.54 \mathrm{mg} / \mathrm{Kg}^{-1}$ and $1510.32 \mathrm{mg} / \mathrm{Kg}^{-1}$ in up and downstream respectively at Chandpur town (Chandpur) of Meghna river.

Table 1.9. The average concentration of $\mathrm{As}, \mathrm{Fe}, \mathrm{Mn}$ and $\mathrm{Cu}$ in different sampling sites of Kushiara and Meghna rivers

\begin{tabular}{|c|c|c|c|c|c|c|}
\hline River & Location & stream & $\begin{array}{c}\text { As } \\
(\mathrm{mg} / \mathrm{Kg})\end{array}$ & $\begin{array}{c}\mathrm{Fe} \\
(\mathrm{g} / \mathrm{Kg})\end{array}$ & $\begin{array}{c}\mathrm{Cu} \\
(\mathrm{mg} / \mathrm{Kg})\end{array}$ & $\begin{array}{c}\mathrm{Mn} \\
(\mathrm{mg} / \mathrm{Kg})\end{array}$ \\
\hline \multirow[t]{4}{*}{ Kushiara } & \multirow[t]{2}{*}{ Beanibazar } & $\begin{array}{c}\text { Beanibazar } \\
\text { upstream }\end{array}$ & 6.56 & 32.32 & 334.20 & 654.27 \\
\hline & & $\begin{array}{c}\text { Beanibazar } \\
\text { downstream }\end{array}$ & 6.28 & 23.39 & 374.75 & 410.20 \\
\hline & \multirow[t]{2}{*}{ Sherpur } & $\begin{array}{l}\text { Sherpur } \\
\text { upstream }\end{array}$ & 5.63 & 16.78 & 299.74 & 454.24 \\
\hline & & $\begin{array}{c}\text { Sherpur } \\
\text { downstream }\end{array}$ & 5.32 & 39.40 & 525.39 & 1138.62 \\
\hline \multirow[t]{4}{*}{ Meghna } & \multirow[t]{2}{*}{ Mohonpur } & $\begin{array}{l}\text { Mohonpur } \\
\text { upstream }\end{array}$ & 5.40 & 20.41 & 268.88 & 378.67 \\
\hline & & downstream & 5.15 & 24.40 & 365.01 & 307.80 \\
\hline & \multirow[t]{2}{*}{ Chandpur } & $\begin{array}{l}\text { Chandpur } \\
\text { upstream }\end{array}$ & 4.83 & 25.27 & 391.78 & 319.54 \\
\hline & & $\begin{array}{c}\text { Chandpur } \\
\text { downstream }\end{array}$ & 4.56 & 24.93 & 465.99 & 510.32 \\
\hline
\end{tabular}


It is clear that highest amount of As $(12.30$ $\mathrm{mg} / \mathrm{Kg}$ ) in sediment occurs at $6 \mathrm{~m}$ depth (table 1. 1) at Beanibazar (Sylhet) in the Kushiara river's upstream and lowest amount (table 1.8) of As $(3.60 \mathrm{mg} / \mathrm{Kg})$ in sediment occurs of the downstream of Meghna river at Chandpur. Arsenic with other metal ions was found in higher amount at upstream of the two rivers. The higher value of arsenic at the borehole sediment of Kushiara River which indicated arsenic in silt and sediment was moving downward toward the Bay of Bengal. Some amount of arsenic might be entered to the ground from the 1-6 m depth. As result, the lower amount of arsenic found in the downstream of the two rivers.

\section{Conclusion}

Arsenic concentration was varied from upper and lower stream in every location due to the geochemical and geophysical aspect of sediments, rock and different ores present in soil. Low amount of arsenic was found in Sherpur (Sylhet) and high amount of arsenic was found in Beanibazar (Sylhet) for Kushiara river. Low amount of arsenic was found in Chandpur town (Chandpur) and high amount of arsenic was found in Mohonpur (Chandpur) for Meghna river. The study suggests that the distribution of arsenic in the sediments is not only controlled by single mineral phase, but arsenic is partitioned into three phases: metal (Fe and $\mathrm{Mn}$ ) hydroxides and Fe sulfides. Arsenic is mobilized from upper stream to lower stream. Statistical analysis shows that arsenic is strongly correlated with $\mathrm{Fe}$ and $\mathrm{Mn}$. $\mathrm{Cu}$ is poorly correlated with arsenic, actually shows no significant influence on as occurrence as it shows correlation magnitude near zero and negative in sign. Higher ratio of Fe/As may be resulted from the presence of soluble Fe-oxides and hydroxides rather than insoluble Fe-silicate in the borehole sediments of the river Kushiara and Meghna.
Authors are acknowledged to the ministry of education government of Bangladesh for financial support to carry out this project.

\section{Disclosure statement}

No potential conflict of interest was reported by the authors.

\section{ORCID}

M. N. E A. Siddique (D): 0000-0002-2077-9491

A. H. M. S. I. M. Jamal D: 0000-0003-0948-1894

\section{Reference}

[1] M.S. Cox, P.F. Bell, J.L. Kover, Plant and Soil, 1996, 180, 11-17.

[2] A. Salam, T. Hossain, M. N. A. Siddique, A. M. Shafiqul Alam, Air Qual. Atmos. Health, 2008, 1, 101-109.

[3] K. Lukkari, M. Leivuori, H. Hartikainen, Biogeochemistry, 2008, 90, 171-191.

[4] K. Kalia, D.B. Khambholja, Handbook of Arsenic Toxicology, 2015, 675-700.

[5] M. Tondel, M. Rahman, A. Magnuson, I.A. Chowdhury, M.H., Faruquee, S.A., Ahmad, Environ. Health Perspect., 1999, 107, 727-729.

[6] C.H. Wang, C.K. Hsiao, C.L. Chen, L.I. Hsu, H.Y. Chiou, S.Y. Chen, Y.M. Hsueh, M.M. Wu, C.J. Chen, Toxicol. Appl. Pharm., 2007, 222, 315-326.

[7] S.C. Mukherjee, M.M. Rahman, U.K. Chowdhury, M.K. Sengupta, D. Lodh, C.R. Chanda, K.C. Saha, D. Chakraborti, J. Environ. Sci. Heal. A, 2003, 38, 165-183.

[8] World Health Organization Guidelines for Drinking-water Quality: Recommendations. Geneva: World Health Organization; $3^{\text {rd }}$ Ed, 1993, pp. 1-11.

[9] World Health Organization. Environmental health criteria 224: arsenic and arsenic compounds, Geneva: World Health Organization, $2^{\text {nd }}$ Ed, 2001. pp. 1-108.

[10] US Environmental Protection Agency. Office of Water Supply, National interim primary drinking water regulations, 1976. 
[11] Allan H. Smith, Elena O. Lingas, \& Mahfuzar Rahman, Bull. World Health Organ, 2000, 78, 1093-1103.

[12] M. Safiuddin, M.M. Karim, Groundwater arsenic contamination in Bangladesh: causes, effects and remediation. In Proceedings of the 1st IEB International Conference and 7th Annual Paper Meet on Civil Engineering, 2001, pp. 2-3.
[13] H. Garelick, H. Jones, A. Dybowska, E. Valsami-Jones, Rev. Environ. Contam. T., 2008, 197, 17-60.

[14] G.S. Pokrovski, S. Kara, J. Roux, Geochim. Cosmochim. Acta, 2002, 66, 2361-2378.

[15] M.F. Hossain, Agr. Ecosyst. Environ., 2006, 113, 1-16.

[16] M.A. Rahman, M.J. Alam, N.E.A. Siddique, A.M. Shafiqul Alam, Dhaka Univ. J. Sci., 2013, 61, 207-210.

How to cite this manuscript: Kazi Mohammad Anamoul Haque, Mohd Nur E Alam Siddique, AHM Shofiul Islam Molla Jamal, Md Anwarul Islam, Mobilization and Distribution of Arsenic with Other Metal Ions at Upstream and Downstream of River Meghna, Adv. J. Chem. A, 2020, 3(3), 358-369. 